\title{
Pelvic, anorectal and urinary symptoms according to the nutritional status of adult women: A cross-sectional study
}

\section{Sintomas pélvicos, anorretais e urinários de acordo com o estado nutricional de mulheres}

\section{adultas: um estudo transversal}

\author{
Karoline Sousa SCARABELOT ${ }^{1}$ iD 0000-0001-5507-9236 \\ Meliza Mercedes Uller ANTUNES² (D) 0000-0001-7022-2782 \\ Andreia PELEGRIN| ${ }^{\text {iD } 0000-0001-8862-9636}$ \\ Janeisa Franck VIRTUOSO2 ${ }^{2}$ 0000-0002-4995-381X
}

\section{A B S T R A C T}

\section{Objective}

To review the occurrence of pelvic, anorectal and urinary symptoms according to the nutritional status of adult women.

\section{Methods}

This is a cross-sectional study with 54 women, aged 18 to 35 years, divided into normal weight $\left(<25 \mathrm{~kg} / \mathrm{m}^{2}\right)$, overweight $\left(25 \mathrm{~kg} / \mathrm{m}^{2}\right.$ to $\left.29.99 \mathrm{~kg} / \mathrm{m}^{2}\right)$ and obesity $\left(\geq 30 \mathrm{~kg} / \mathrm{m}^{2}\right)$ according to the body mass index. The presence of

1 Universidade do Estado de Santa Catarina, Centro de Ciências da Saúde e do Esporte, Programa de Pós-Graduação em Ciências do Movimento Humano. Araranguá, SC, Brasil.

2 Universidade Federal de Santa Catarina, Centro Araranguá, Departamento de Ciências da Saúde, Programa de Pós-Graduação em Ciências da Reabilitação. Rod. Governador Jorge Lacerda, 3201. Jardim das Avenidas, 88906-072, Araranguá, SC, Brasil. Corresponde to: JF VIRTUOSO E-mail: <janeisa.virtuoso@ufsc.br>.

${ }^{3}$ Universidade do Estado de Santa Catarina, Centro de Ciências da Saúde e do Esporte, Programa de Pós-Graduação em Ciências do Movimento Humano. Florianópolis, SC, Brasil.

Support: This study was financed in part by the Coordenação de Aperfeiçoamento de Pessoal de Nivel Superior (Finance Code 001).

Article based on the dissertation by KS SCARABELOT, entitled "Disfunções dos músculos do assoalho pélvico e medidas antropométricas em mulheres adultas”. Universidade Federal de Santa Catarina; 2018.

\section{How to cite this article}

Scarabelot KS, Antunes MMU, Pelegrini A, Virtuoso JF. Pelvic, anorectal and urinary symptoms according to the nutritional status of adult women: A cross-sectional study. Rev Nutr. 2019;32:e180257. http://dx.doi.org/10.1590/1678-98 $65201932 \mathrm{e} 180257$ 
pelvic floor muscle dysfunction symptoms was assessed by the Pelvic Floor Distress Inventory and the impact of these symptoms by the Pelvic Floor Impact Questionnaire. Descriptive and inferential statistics were used, with a significance level of $5 \%$.

\section{Results}

Pelvic Floor Distress Inventory total score was 22.95 (SD=26.11) in the eutrophic group and 59.67 (SD=47.80) in the obesity group $(p=0.01)$. Considering the scales, urinary symptoms were higher in obese women than in the eutrophic group $(p=0.01)$. In the assessment of patients with each symptom, a difference $(p<0.01)$ was observed in incomplete bowel emptying, in which the highest frequency occurred in overweight women (47.4\%) compared to eutrophic and obese women (both $26.3 \%)$. Urinary incontinence symptoms (18.2\% in eutrophic women, $27.3 \%$ overweight and $54.5 \%$ obese), stress urinary incontinence (8.3\% eutrophic, $41.7 \%$ overweight and $50.0 \%$, obese) and difficulty in emptying the bladder (0.0\% eutrophic, $33.3 \%$ overweight and $66.7 \%$ obese) exhibited higher frequencies ( $p=0.03 ; p<0,01$ and $p=0.02$, respectively) in obese women.

\section{Conclusion}

Symptoms of pelvic floor muscles dysfunction, especially urinary tract muscles, occur more frequently in obese adult women when compared to eutrophic women.

Keywords: Body mass index. Constipation. Obesity. Overweight. Urinary incontinence.

\section{RE S U M O}

\section{Objetivo}

Analisar a presença dos sintomas pélvicos, anorretais e urinários de acordo com o estado nutricional de mulheres adultas.

\section{Métodos}

Trata-se de um estudo transversal com 54 mulheres, com idade entre 18 e 35 anos, divididas nas seguintes categorias: eutróficas $\left(<25 \mathrm{~kg} / \mathrm{m}^{2}\right)$, com sobrepeso $\left(25 \mathrm{~kg} / \mathrm{m}^{2}\right.$ a $\left.29,99 \mathrm{~kg} / \mathrm{m}^{2}\right)$ e com obesidade $\left(\geq 30 \mathrm{~kg} / \mathrm{m}^{2}\right)$, de acordo com o índice de massa corporal. A presença dos sintomas das disfunções dos músculos do assoalho pélvico foi avaliada por meio do Pelvic Floor Distress Inventory, e o impacto desses sintomas pelo Pelvic Floor Impact Questionnaire. Utilizou-se estatística descritiva e inferencial com nível de significância de 5\%.

\section{Resultados}

O escore total do Pelvic Floor Distress Inventory apresentou média de 22, $95(D P=26,11)$ no grupo eutrófico e $59,67(D P=47,80)$ no grupo obesidade $(p=0,01)$. Entre as escalas, os sintomas urinários apresentaram valores maiores nas mulheres com obesidade em relação ao grupo eutrófico $(p=0,01)$. Na associação entre cada sintoma, encontrou-se diferença $(p<0,01)$ no esvaziamento incompleto do intestino, cuja maior frequência ocorreu nas mulheres com sobrepeso (47,4\%) em comparação às eutróficas e com obesidade (ambas 26,3\%). Nos sintomas de incontinência urinária de urgência (18,2\% nas mulheres eutróficas, 27,3\% nas mulheres com sobrepeso e $54,5 \%$ nas mulheres obesas), de incontinência urinária de esforço (8,3\% nas mulheres eutróficas, 41,7\% nas mulheres sobrepeso e 50,0\% nas obesas) e de dificuldade em esvaziar a bexiga (0,0\% nas eutróficas, 33,3\% nas mulheres com sobrepeso e 66,7\% nas mulheres obesas), foram verificadas frequências maiores $(p=0,03 ; p<0,01$ e $p=0,02$, respectivamente) nas mulheres com obesidade.

\section{Conclusão}

Os sintomas de disfunções dos músculos do assoalho pélvico, sobretudo os urinários, ocorrem mais em mulheres adultas obesas em comparação às mulheres adultas eutróficas.

Palavras-chave: Índice de massa corporal. Constipação intestinal. Obesidade. Sobrepeso. Incontinência urinária.

\section{NTRODUCTION}

Pelvic Floor Muscle Dysfunction (PFMD) includes bladder, bowel, sexual, and pelvic pain disorders [1]. These dysfunctions include: Urinary Incontinence (UI), Anal Incontinence (AI), and Pelvic Organ Prolapse (POP), respectively, defined as the complaint of involuntary loss of urine, involuntary 
loss of stool and/or flatus, and descent either isolated or together with the anterior vaginal wall, posterior vaginal wall, cervix or vagina apex [2]. PFMD occurs in $25 \%$ of women [3] and these symptoms often coexist [4] with impact on quality of life [5-7].

The prevalence of these dysfunctions can be explained by factors such as family history, age, menopause, obstetric history [8], gynecological cancer [9] and obesity [10]. Among those factors, overweight and obesity stand out, and Romero-Talamás et al. [11] observed that the mean total pelvic floor symptom score decreased from $76.7(\mathrm{SD}=47.2)$ to $52.2(\mathrm{SD}=50.9)$ after bariatric surgery in morbidly obese women.

There is much evidence in the literature associating overweight and PFMD [12-14]; however, most studies have been conducted in middle-aged or elderly women [15-17], offering little information on young adult women. Knowledge about the influence of overweight/obesity on PFMD symptoms in adult women may help in the prevention of PFMD that will reflect on the reduction of symptoms in older age, as well as on the clarification of those comorbidities in this population, since overweight. and obesity are already established as risk factors for the development of PFMD in the elderly $[17,18]$. Thus, the aim of the present study was to analyze the occurrence of pelvic, anorectal and urinary symptoms according to the nutritional status of adult women.

\section{METHOD S}

This is a cross-sectional study written according to Strengthening the Reporting of Observational Studies in Epidemiology recommendations. In this study, we investigated the presence of PFMD symptoms in three patient groups categorized according to Body Mass Index (BMI). The overweight group included women with a BMI between $25 \mathrm{~kg} / \mathrm{m}^{2}$ and $29.99 \mathrm{~kg} / \mathrm{m}^{2}$, while the obesity group consisted of women with a BMI $\geq 30 \mathrm{~kg} / \mathrm{m} 2$ while the eutrophic group comprised women with $\mathrm{BMl}<25 \mathrm{~kg} / \mathrm{m}^{2}[19]$.

Inclusion criteria were women aged 18 to 35 years, regardless of parity, mode of delivery and regular physical activity. Pregnant women, professional and amateur athletes, women who underwent bariatric surgery, total hysterectomy and who reported symptoms of urinary infection were excluded.

After approval by the Research Ethics Committee under the opinion report number 1,661,484, an invitation was released through disclosure in the social networks and Unidades Básicas de Saúde (UBS, Health Basic Units) in Araranguá (SC), municipality, to participate in the investigation, which characterized a convenience sampling. The sample was selected upon patients' acceptance to participate in the study and their meeting the inclusion criteria.

To characterize the sample, we collected, in interviews, sociodemographic data (education and marital status), clinical data (age), gynecological data (use of contraceptive methods), obstetric data (pregnancy and vaginal delivery), hereditary data (PFMD family history) and behavioral (having a partner, sexually active and practicing regular physical activity).

The presence of PFMD symptoms was assessed by complementary questionnaires. Pelvic Floor Distress Inventory (PFDI-20) and Pelvic Floor Impact Questionnaire (PFIQ-7). The PFDI-20 assesses the presence of specific pelvic floor symptoms, including pelvic, anorectal, and urinary symptoms. These symptoms are evaluated using the three scales, Pelvic Organ Prolapse Distress Inventory (POPDI-6), Colorectal-Anal Distress Inventory (CRADI-8) and Urinary Distress Inventory (UDI-6) respectively, which, together, characterize the total score of the PFDI-20. Each scale provides a score and the sum 
of the three scales a total score. The items in PFDI-20 are questions first on whether each symptom is experienced (yes or no) and if "yes" the degree of discomfort, which is rated on a scale ranging from one (none) to four (quite).

Regarding the impact caused by the symptoms, the Pelvic Floor Impact Questionnaire (PFIQ-7) was applied, which also exhibits scales (bladder, bowel and vagina or pelvis) and assesses the impact of symptoms on the ability to perform household chores, physical activities, entertainment, travel, social activities, emotional health and feelings of frustration on a scale ranging from zero (not at all) to three (quite). The two questionnaires generate a score from 0 to 300 points in which higher scores indicate worsening of symptoms and greater impact, with each scale providing a score from 0 to 100 points [20]. PFDI-20 and PFIQ-7 were developed by Barber et al. [21] and their translation to Portuguese was validated by Arouca et al. [22]. These questionnaires, besides being short, are considered reliable in identifying PFMD symptoms [23].

Regarding anthropometric measurements, the following variables were evaluated: body mass, using a $0.1 \mathrm{~kg}$ resolution G-Tech digital portable scale for weight, and a $0,5 \mathrm{~cm}$ resolution portable Sanny stadiometer for height measurements. Participants were instructed to be barefoot and to wear as little clothing as possible. All measurements were performed by a single female evaluator following the standardization of the International Society for the Advancement of Kinanthropometry (ISAK) [24]. BMI was calculated by dividing body mass (in $\mathrm{kg}$ ) by the square of height $\left(\mathrm{m}^{2}\right)$ and categorized as eutrophic, overweight and obese [19]. BMI was the anthropometric variable chosen because it is the most widely used variable in the literature to define overweight and obesity in women with PFMD [25-28]. Thus, comparisons between different populations could be performed.

\section{Procedures}

Data collection took place between October 2017 and February 2018 in a private physiotherapy clinic in Araranguá (SC), in order to provide greater privacy to participants. When data collection was scheduled, participants received guidance to ensure greater control of anthropometric variables, such as not performing strenuous physical exercise before the evaluation; do not intake food, alcohol or caffeine 3 hours before the evaluation; have slept for 6 to 8 hours the day before the assessment; drink plenty of water over the 24 hours prior to the test [29].

After signing the Free and Informed Consent Form, data collection procedures were initiated. These procedures took place in three stages, performed on the same day. First, sociodemographic, clinical, gynecological and obstetric data were evaluated. Then, anthropometric measurements were carried out and questionnaires were applied to investigate the presence of PFMD symptoms (PFDI-20 and PFIQ-7).

The data collected were stored in a database in the Microsoft Excel ${ }^{\circledR}$ program and each participant was registered according to an encoding number. Statistical analysis was performed in the IBM ${ }^{\circledR}$ SPSS $^{\circledR}$ Statistics (20.0) package. Initially, all variables were analyzed descriptively by absolute and relative frequency (categorical variables) and measures of position and dispersion (numerical variables). The Kolmogorov-Smirnov test was used to verify the normality of the data. To verify possible associations between categorical variables, the Chi-square test $\left(\chi^{2}\right)$ or Fisher's Exact Test was used, when necessary. For comparison between three groups, the Kruskal-Wallis post hoc Dunn test was performed. A significance level of $5 \%$ was adopted. 
A sample calculation was performed a posteriori using the G Power software, so that overweight women had a total PFDI-20 score of 48.95 (SD=34.57), obese women $\bar{x}=59.57, \mathrm{SD}=47.80$ ) and eutrophic women $(\bar{x}=22.95, S D=26.11)$. Thus, the effect size $(d=0.45)$, significance level $(0.05)$ and power of the study (0.82) were observed.

\section{R E S U L T S}

The study included 54 women with a mean age of 26.52 years $(S D=4.48) ; 59.3 \%$ were single and $35.2 \%$ had incomplete higher education. Among the participants, according to their $\mathrm{BMI}, 27$ were eutrophic $(\bar{x}=21.93 ; S D=1.70), 13$ exhibited overweight $(\bar{x}=27.78 ; S D=1.30)$ and 14 , obesity $(\bar{x}=34.27 ; \mathrm{SD}=2.90)$.

The variables age, family history, contraceptive method, being sexually active, having a partner, regular physical activity, pregnancy and type of delivery were verified as possible factors associated with the presence of PFMD symptoms (Table 1).

Comparing the total PFMD symptom score between overweight, obesity and eutrophic groups, a significant difference was observed between the eutrophic and obesity groups with a high effect size $(\mathrm{d}=0.99)$. When comparing urinary symptoms between overweight, obesity and eutrophic groups, a significant difference was observed between the eutrophic and common obesity groups with 1.03 effect size (Table 2). However, when comparing pelvic and anorectal

Table 1. Comparison and association of variables inherent to the symptoms of pelvic floor muscle dysfunction with women divided into eutrophic ( $n=27)$, overweight $(n=13)$ and obesity ( $n=14)$ groups. Araranguá (SC), 2018.

\begin{tabular}{|c|c|c|c|c|c|c|c|}
\hline \multirow{2}{*}{ Associated Factors } & \multicolumn{2}{|c|}{ Eutrophic } & \multicolumn{2}{|c|}{ Overweight } & \multicolumn{2}{|c|}{ Obesity } & \multirow{2}{*}{$p$ value } \\
\hline & $n$ & $\%$ & $n$ & $\%$ & $n$ & $\%$ & \\
\hline Age & $\bar{x}=25.41$ & $S D=4.44$ & $\bar{x}=28$ & $S D=4.32$ & $\bar{x}=27.29$ & $S D=4.46$ & 0.18 \\
\hline Family History & 19 & 55.90 & 5 & 14.70 & 10 & 29.40 & 0.11 \\
\hline Contraceptive method use & 21 & 51.20 & 9 & 22.00 & 11 & 26.80 & 0.80 \\
\hline Have a partner & 21 & 48.80 & 11 & 25.60 & 11 & 25.60 & 0.87 \\
\hline Be sexually active & 23 & 48.90 & 12 & 25.50 & 12 & 25.50 & 0.81 \\
\hline Physical activity practice & 18 & 52.90 & 7 & 20.60 & 9 & 26.50 & 0.72 \\
\hline Gestated & 3 & 16.70 & 6 & 33.30 & 9 & 50.00 & $<0.01$ \\
\hline Vaginal Delivery & 1 & 12.50 & 7 & 87.50 & 8 & 44.40 & 0.64 \\
\hline
\end{tabular}

Note: $\bar{x}$ : Average; SD: Standard Deviation; n: Absolute frequency; \%: Relative frequency.

Table 2. Comparison of Pelvic Floor Distress Inventory-20 total score and urinary symptoms between groups categorized according to Body Mass Index. Araranguá (SC), 2018.

\begin{tabular}{|c|c|c|c|c|c|c|}
\hline \multirow{2}{*}{ Groups } & \multicolumn{2}{|c|}{ Total score PFDI-20 } & \multirow{2}{*}{$p$ value } & \multicolumn{2}{|c|}{ Urinary symptoms } & \multirow{2}{*}{$p$ value } \\
\hline & $\bar{x}$ & SD & & $\bar{x}$ & SD & \\
\hline Eutrophic $^{a}$ & 22.95 & 26.11 & & 6.79 & 11.62 & \\
\hline Overweight ${ }^{\mathrm{ab}}$ & 48.95 & 34.57 & 0.01 & 18.27 & 18.91 & 0.01 \\
\hline Obesity $^{\mathbf{b}}$ & 59.67 & 47.80 & & 26.48 & 26.48 & \\
\hline
\end{tabular}

Note: ${ }^{\text {a,b }}$ Distinct letters represent difference; $\bar{x}$ : Average; SD: Standard Deviation. 
symptom scores between groups, no significant differences were observed with $p=0.16$ and $p=0.14$, respectively.

In the analysis of the impact caused by pelvic, anorectal and urinary symptoms (Pelvic Organ Prolapse Impact Questionnaire [POPIQ-7], Colorectal-Anal Impact Questionnaire [CRAIQ-7], and Urinary Impact Questionnaire [UIQ-7]), the overweight, obesity and eutrophic groups showed no significant difference $(p>0.05)$.

The association of each symptom evaluated by PFDI-20 and the nutritional status was also determined. Thus, it can be observed that the symptom "feeling of incomplete bowel emptying" is more prevalent in overweight women, while the symptoms "urge urinary incontinence", "stress urinary incontinence" and "difficulty emptying the bladder" are more prevalent in women with obesity (Table 3).

Pelvic floor muscle dysfunction symptoms were also analyzed based on the gestational variable (which was different between the eutrophic, overweight and obesity groups). However, there was no difference between groups ( $p>0.05)$, indicating that when stratifying the sample into primiparous/multiparous and nulliparous, symptoms were similar in eutrophic, overweight and obese women, although a large variability of data can be observed.

Table 3. Association between PFDI-20 symptoms and eutrophic, overweight and obesity groups ( $n=54)$. Araranguá (SC), 2018.

\begin{tabular}{|c|c|c|c|c|c|c|c|}
\hline \multirow{2}{*}{ PFDI-20 symptoms } & \multicolumn{2}{|c|}{ Eutrophic } & \multicolumn{2}{|c|}{ Overweight } & \multicolumn{2}{|c|}{ Obesity } & \multirow{2}{*}{$p$} \\
\hline & f & $\%$ & $f$ & $\%$ & f & $\%$ & \\
\hline Low belly pressure feeling & 2 & 18.20 & 4 & 36.40 & 5 & 45.50 & 0.06 \\
\hline Hardening / loosening underbelly & 3 & 25.00 & 5 & 41.70 & 4 & 33.33 & 0.12 \\
\hline See or feel a "ball" in the vagina & 2 & 40.00 & 1 & 20.00 & 2 & 40.00 & 0.75 \\
\hline Push something with fingers for complete evacuation & 1 & 50.00 & 0 & 0 & 1 & 50.00 & 0.62 \\
\hline Feeling of incomplete bladder emptying & 5 & 29.40 & 5 & 29.40 & 7 & 41.20 & 1.00 \\
\hline Push something with fingers to urinate & 0 & 0 & 0 & 0 & 0 & 0 & - \\
\hline Force to evacuate & 10 & 45.50 & 7 & 31.80 & 5 & 22.70 & 0.54 \\
\hline Feeling of incomplete bowel emptying & 5 & 26.30 & 9 & $47.40^{¥}$ & 5 & 26.30 & $<0.01$ \\
\hline Lose solid stools & 0 & 0 & 0 & 0 & 1 & 100.00 & 0.23 \\
\hline Lose liquid stools & 0 & 0 & 0 & 0 & 0 & 0 & - \\
\hline Eliminates flatus involuntarily & 6 & 60.00 & 1 & 10.00 & 3 & 30.00 & 0.51 \\
\hline Pain on bowel movement & 6 & 31.60 & 7 & 36.80 & 6 & 31.60 & 0.11 \\
\hline Strong sense of urgency to evacuate & 7 & 43.80 & 2 & 12.50 & 7 & 43.80 & 0.12 \\
\hline "Ball" in the genital region after evacuating & 1 & 100.00 & 0 & 0 & 0 & 0 & 0.60 \\
\hline Polyuria & 3 & 30.00 & 4 & 40.00 & 3 & 30.00 & 0.31 \\
\hline UUI symptom & 2 & 18.20 & 3 & 27.30 & 6 & $54.50^{*}$ & 0.03 \\
\hline SUI symptom & 1 & 8.30 & 5 & 41.70 & 6 & $50.00^{*}$ & $<0.01$ \\
\hline Losing urine in small amounts drops & 6 & 40.00 & 4 & 26.70 & 5 & 33.33 & 0.63 \\
\hline Difficulty emptying the bladder & 0 & 0 & 2 & 33.33 & 4 & $66.70^{*}$ & 0.02 \\
\hline Pain/discomfort in the lower abdomen or genital region & 4 & 30.80 & 3 & 23.10 & 6 & 46.20 & 0.14 \\
\hline
\end{tabular}

Note: ¥: Residual adjustment above 2.0; f: Absolute frequency in answering "yes"; \%: Relative frequency in answering "yes"; UUI: Urinary Urge Incontinence; IUE: Stress Urinary Incontinence. 


\section{DISCUSSION}

The present study showed that women with obesity have a higher presence of PFMD, with predominance of urinary symptoms. When investigating each symptom, there was a higher frequency of "feeling of incomplete bowel emptying" in the overweight group and "Stress Urinary Incontinence (SUI) symptoms", UI symptoms and "difficulty in emptying the bladder" in the obesity group. Moreover, the presence of PFMD symptoms did not show any difference between the eutrophic, overweight and obesity groups when considering nulliparous, primiparous or multiparous women.

The presence of PFMD has also been found in other studies in the literature, being more prevalent in overweight or obese women over 40 years of age [17,30,31]. Although, in the present study, the participants were young, Ghandour et al. [32], in a study with 900 women, found a greater presence of PFMD in women over 60 years of age and in overweight women, suggesting such conditions to be a risk factor for PFMD.

Nevertheless, Lu et al. [33] identified, in women aged 35 to 75 years $(n=1067)$, that overweight women had 3.37 (95\% Cl:1.24-9.12) times more chance of. Dellú et al. [31], interviewing 998 women, also evidenced that overweight women exhibited $86 \%(95 \% \mathrm{Cl}: 1.17-2.86)$ more chances of Ul. Similarly, Romero-Talamás et al. [11] in a study with 72 women found a higher incidence of urinary symptoms, according to PFDI-20 results, in women with a BMI of $47.5 \pm 9.4 \mathrm{~kg} / \mathrm{m}^{2}$. Still, a study conducted with elderly women $(n=562)$ found that overweight was associated with UI symptoms [34].

The findings of this study differ from the results obtained by Brucker et al. [35], because obesity was associated with the presence of $\mathrm{UI}$ in women with less than 35 years of age. This association can be explained by the fact that excess weight impairs pelvic floor function through chronic increase in intra-abdominal pressure, which leads to increased bladder pressure and to urethral hypermobility, leading to UI. [36].

In the present study, a significant difference was observed between the groups regarding "feeling of incomplete bowel emptying". Women with high BMI are $32 \%$ more likely to experience the feeling of incomplete bowel emptying than women with normal $\mathrm{BMI}(\mathrm{OR}=1.32,95 \% \mathrm{Cl}: 1.03-1.71)$ [37]. Thus, these findings corroborate Huang et al. [38] who stated that BMI above $25 \mathrm{~kg} / \mathrm{m}^{2}$ can be considered a risk factor (OR=2.34, 95\% Cl:1.34-4.08) for constipation.

Incomplete bowel emptying is one of the symptoms that may affect constipated individuals [39], since, along with overweight, psychological stress, infrequent consumption of fruits and vegetables, frequent irritability were seen as explanations for constipation [40].

In the present study the urinary symptoms associated with obesity were "UUI symptoms" (81.8\%) and "SUI symptoms" (91.7\%). Similar findings were obtained by Romero-Talamás et al. [11] $(n=72)$ where SUI was the most prevalent dysfunction (83.3\%) in overweight or obese women. A study $(n=8,000)$ noted that women with a BMl greater than $35 \mathrm{~kg} / \mathrm{m}^{2}$ are more likely to have mixed UI, while women with a BMI lower than $35 \mathrm{~kg} / \mathrm{m}^{2}$ are more likely to have SUI [17]. Pomiam et al. [12] state that obesity influences many types of lower urinary tract symptoms, including different types of urinary incontinence.

Another risk factor related to PFMD is pregnancy [41-43]. In this study, most women with obesity had experienced pregnancy at least once (62.5\%). Oversand et al. [15] also reported that parity was significantly associated with urinary symptoms in women with $24.9 \mathrm{~kg} / \mathrm{m}^{2} \mathrm{BMl}$ and 61 years mean age. Although this difference was observed when analyzing the PFMD between 
eutrophic and overweight/obesity groups, no difference was found in nulliparous and primiparous/ multiparous women. Knepfler et al. [44] also found no difference when comparing continence disorders between nulliparous and primiparous or multiparous women. However, Barbosa et al. [45] found that overweight and obesity before pregnancy was not determined as a risk factor for UI $(\mathrm{OR}=1.45 ; 95 \% \mathrm{Cl}: 0.95-2.23)$; however, overweight and obesity during pregnancy represented a risk factor $(\mathrm{OR}=1.53 ; 95 \% \mathrm{Cl}: 1.28-1.83)$.

Most studies found in the literature address middle-aged or older women, making the findings with young women important for understanding how PFMD behave in overweight women. Although the sample small number can be considered a limitation, the statistical analysis showed a good study power (0.82) which may represent the population.

A limitation of the present study may be the fact that symptoms were self-reported. Therefore more objective measures to identify dysfunctions such as urodynamic studies and pelvic ultrasound would yield more accurate results. It is also possible that a higher proportion of women who had any symptoms showed interest in participating in the study. In addition, cross-sectional studies do not allow cause and effect inferences.

Finally, healthcare professionals who take care of obese women should recognize PFMD symptoms as comorbidities, and future studies should evaluate whether these obesity comorbidities can be reduced through successful weight reduction interventions as well as health promotion in order to advise adult women about the risks of these symptoms.

\section{CONCLUSION}

The presence of pelvic floor muscle dysfunctions, especially those associated with urinary symptoms can be observed more frequently in obese women compared to eutrophic women.

\section{CONTRIBUTORS}

KS SCARABELOT developed the conception and design of the study, analysis and interpretation of data and scientific writing of the final article. MMU ANTUNES and A PELEGRINI performed data analysis and interpretation and scientific writing of the final article. JF VIRTUOSO conducted data analysis and interpretation and scientific writing of the final article.

\section{REFERE N CES}

1. Bo K, Frawley HC, Haylen BT, Abramov Y, Almeida FG, Berghmans B, et al. An International Urogynecological Association (IUGA)/International Continence Society (ICS) joint report on the terminology for the conservative and nonpharmacological management of female pelvic floor dysfunction. Neurourol Urodyn. 2017;36(2):221-44. http://.dx.doi.org/10.1002/nau.23107

2. Haylen BT, Dirk R, Freeman RM, Swift SE, Berghmans B, Lee J, et al. An International Urogynecological Association (IUGA)/International Continence Society (ICS) joint report on the terminology for female pelvic floor dysfunction. Neurourol Urodyn. 2010;29(1):4-20. http://dx.doi.org/10.1007/s00192-009-0976-9

3. Wu JM, Vaughan CP, Goode PS, Redden DT, Burgio KL, Richter HE, et al. Prevalence and trends of symptomatic pelvic floor disorders in U.S. women. Obstet Gynecol. 2014;123(1):141-8. http://dx.doi.org/10.1097/AOG. 0000000000000057

4. Santoro GA. Imaging the pelvic floor. Tech Coloproctol. 2017;21(7):497-9. http://dx.doi.org/10.1007/s10 151-017-1668-y 
5. Nygaard CC, Schreiner L, Morsch TP, Saadi RP, Figueiredo MF, Padoin AV. Urinary incontinence and quality of life in female patients with obesity. Rev Bras Ginecol Obstet. 2018;40(9):534-9. http://dx.doi. org/10.1055/s-0038-1670626

6. Lopes MHBM, Costa JN, Bicalho MB, Casale TE, Camisão AR, Fernandes MLV. Profile and quality of life of women in pelvic floor rehabilitation. Rev Bras Enferm. 2018;71(5):2496-505. http://dx. doi.org/10.1590/00347167-2017-0602

7. Türkcü SG, Kukulu K. Urinary incontinence and quality of life of women living in nursing homes in the Mediterranean region of Turkey. Psychogeriatrics. 2017;17(6):446-52. http://dx.doi.org/10.1111/psyg.12271

8. Rodríguez-Mias NL, Martínez-Franco E, Aguado J, Sánchez E, Amat-Tardiu L. Pelvic organ prolapse and stress urinary incontinence, do they share the same risk factors? Eur J Obstet Gynecol Reprod Biol. 2015;190:52-7. http://dx.doi.org/10.1016/j.ejogrb.2015.04.015

9. Ramaseshan AS, Felton J, Roque D, Rao G, Shipper AG, Sanses TVD. pelvic floor disorders in women with gynecologic malignancies: A systematic review. Int Urogenececol J. 2017;29(4)459-76. http://dx.doi. org/10.1007/s00192-017-3467-4

10. Pomian A, Majkusiak W, Lisik W, Tomasik P, Horosz E, Zwierzchowska A, et al. Is bariatric surgery a prophylaxis for pelvic floor disorders? Obes Surg. 2017;28(6):1653-8. http://dx.doi.org/10.1007/s00192-017-3467-4

11. Romero-Talamás H, Unger CA, Aminian A, Schauer PR, Barber M, Brethauer S. Comprehensive evaluation of the effect of bariatric surgery on pelvic floor disorders. Surg Obes Relat Dis. 2016;12(1):138-43. http://dx.doi. org/10.1016/j.soard.2015.08.499

12. Pomian A, Lisik W, Kosieradzki M, Barcz E. Obesity and pelvic floor disorders: A review of the literature. Med Sci Monit. 2016;22:1880-6.

13. Islam RM, Bella RJ, Hossainb MB, Davisa SR. Types of urinary incontinence in Bangladeshi women at midlife: Prevalence and risk factors. Maturitas. 2018;116:18-23.

14. Swenson CW, Kolenic GE, Trowbridge ER, Berger MB, Lewicky-Gaupp C, Margulies RU, et al. Obesity and stress urinary incontinence in women: Compromised continence mechanism or excess bladder pressure during cough? Int Urogynecol J. 2017;28(9):1377-85. http://dx.doi.org/10.1007/s00192-017-3279-6

15. Oversand SH, Staff AC, Sandvik L, Volløyhaug I, Svenningsen R. Levator ani defects and the severity of symptoms in women with anterior compartment pelvic organ prolapse. Int Urogynecol J. 2018;29(1):63-9. http://dx.doi.org/10.1007/s00192-017-3390-8

16. Neto IJFC, Pinto RA, Jorge JMN, Santo MA, Bustamante-Lopez LA, Cecconello I, et al. Are obese patients at an increased risk of pelvic floor dysfunction compared to non-obese patients? Obes Surg. 2017;27(7):182227. http://dx.doi.org/:10.1007/s11695-017-2559-z

17. Pedersen LS, Lose G, Høybye MT, Elsner S, Waldmann A, Rudnicki M. Prevalence of urinary incontinence among women and analysis of potential risk factors in Germany and Denmark. Acta Obstet Gynecol Scand. 2017;96(8):939-48. http://dx.doi.org/10.1111/aogs.13149

18. Zeleke BM, Bell RJ, Billah B, Davis SR. Symptomatic pelvic floor disorders in community-dwelling older Australian women. Maturitas. 2016;85:34-41. http://dx.doi.org/10.1016/j.maturitas.2015.12.012

19. World Health Organization. Global status report on non-communicable diseases 2010. Geneva: WHO; 2011.

20. Harvie HH, Lee DD, Uduak UA, Shea JA, Arya LA. Validity of utility measures for women with pelvic organ prolapse. Am J Obstet Gynecol. 2017;218(1)119. http://dx.doi.org/10.1016/j.ajog.2017.09.022

21. Barber MD, Kuchibhatla MN, Pieper CF, Bump RC. Psychometric evaluation of 2 comprehensive condition-specific quality of life instruments for women with pelvic floor disorders. Am J Obstet Gynecol. 2001;185(6)1388-95. http://dx.doi.org/10.1067/mob.2001.118659

22. Arouca MA, Duarte TB, Lott DA, Magnani PS, Nogueira AA, Rosa-e-Silva JC, et al. Validation and cultural translation for Brazilian Portuguese version of the Pelvic Floor Impact Questionnaire (PFIQ-7) and Pelvic Floor Distress Inventory (PFDI-20). Int Urogynecol J. 2016;27(7):1097-106. http://dx.doi.org/10.1007/s00192-0152938-8

23. Barber MD, Walters MD, Bump RC. Short forms of two condition-specific quality-of-life questionnaires for women with pelvic floor disorders (PFDI-20 and PFIQ-7). Am J Obstet Gynecol. 2005;193(1):103-13. http:// dx.doi.org/10.1016/j.ajog.2004.12.025

24. Canadian Society for Exercise Physiology. The Canadian physical activity, fitness and lifestyle appraisal, CSEP's guide to health active living. 3nd ed. Ottawa: CSEP; 2004. 
25. Subak L, King WC, Belle SH, Chen J, Courcoulas AP, Ebel FE, et al. Urinary incontinence before and after bariatric surgery. Jama Intern Med. 2015;175(8):1378-87. http://dx.doi.org/10.1001/jamainternmed.2015.2609

26. Suskind AM, Cawthon PM, Nakagawa S, Subak LL, Reinders I, Satterfield S, et al. Urinary incontinence in older women: The role of body composition and muscle strength from the health, aging, and body composition study. Am Geriatr Soc. 2017;65(1):42-50. http://dx.doi.org/10.1111/jgs.14545

27. Bohlin KS, Ankardal M, Nüssler E, Lindkvist $\mathrm{H}$, Milsom I. Factors influencing the outcome of surgery for pelvic organ prolapse. Int Urogynecol J. 2018;29(1):81-9. http://dx.doi.org/10.1007/s00192-017-3446-9

28. Jeong SJ, Lee HS, Lee JK, Jeong JW, Lee SC, Kim JH, et al. The long-term influence of body mass index on the success rate of mid-urethral sling surgery among women with stress urinary incontinence or stresspredominant mixed incontinence: Comparisons between retropubic and transobturator approaches. Plos One. 2014;9(11):e113517. http://dx.doi.org/10.1371/journal.pone.0113517

29. American College of Sports Medicine. Manual do ACSM para avaliação da aptidão física relacionado à saúde. 3a ed. Rio de Janeiro: Guanabara Koogan; 2011.

30. Moreno-Vecino B, Arija-Blázquez A, Pedrero-Chamizo R, Alcázar J, Gómez-Cabello A, Pérez-López FR, et al. Associations between obesity, physical fitness, and urinary incontinence in non-institutionalized postmenopausal women: The elderly EXERNET multi-center study. Maturitas. 2015;82(2):208-14. http:// dx.doi.org/10.1016/j.maturitas.2015.07.008

31. Dellú MC, Schmitt AC, Cardoso MR, Pereira WM, Pereira EC, Vasconcelos ES, et al. Prevalence and factors associated with urinary incontinence in climacteric. Rev Assoc Med Bras. 2016;62(5):441-6. http://dx.doi. org/10.1590/1806-9282.62.05.441

32. Ghandour L, Minassian V, Al-Badr A, Abou Ghaida R, Geagea S, Bazi T. Prevalence and degree of bother of pelvic floor disorder symptoms among women from primary care and specialty clinics in Lebanon: An exploratory study. Int Urogynecol J. 2017;28(1):105-18. http://dx.doi.org/10.1007/s00192-016-3080-y

33. Lu S, Zhang H, Zhang Y, Shao QC. Prevalence and risk factors of urinary incontinence among perimenopausal women in Wuhan. J Huazhong Univ Sci Technol. 2016;36(5):723-6. http://dx.doi.org/10.1007/s11596-0161651-2

34. Tavares DMS, Bolina AF, Dias FA, Ferreira PCS, Santos NMF. Excesso de peso em idosos rurais: associação com as condições de saúde e qualidade de vida. Ciênc Saúde Colet. 2018;23(3):913-22. http://dx.doi. org/10.1590/1413-81232018233.25492015

35. Brucker J, Wagner I, Rudofsky G, Rauch G, Sohn C, Brocker KA. In obesity even young women suffer from urogynecological symptoms. Arch Gynecol Obstet. 2017;296(5):947-56. http://dx.doi.org/10.1007/s00404017-4514-6

36. Ramalingam K, Monga A. Obesity and pelvic floor dysfunction. Best Pract Res Clin Obstet Gynaecol. 2015;29(4):541-7. http://dx.doi.org/10.1016/j.bpobgyn.2015.02.002

37. Eslick GD. Gastrointestinal symptoms and obesity: A meta-analysis. Obes Rev. 2012;13(5):469-79. http:// dx.doi.org/10.1111/j.1467-789X.2011.00969.x

38. Huang L, Jiang H, Zhu M, Wang B, Tong M, Li H, et al. Prevalence and risk factors of chronic constipation among women aged 50 years and older in Shanghai, China. Med Sci Monit. 2017;23:266-7. http://dx.doi. org/10.12659/msm.90404

39. Drossman DA. Functional gastrointestinal disorders: History, pathophysiology, clinical features, and Rome IV. Gastroenterology. 2016;150:1262-79.

40. Yamada M, Sekine M, Tatsuse T. Psychological stress, family environment, and constipation in japanese children: The Toyama birth cohort study. J Epidemiol. 2019;29(6):220-6. http://dx.doi.org/10.2188/jea. JE20180016

41. Zuchelo LTS, Santos EFS, Figueiredo FWS, Adami F, Bezerra IMP, Raimundo RD, et al. Pelvic floor disorders in postpartum adolescents in the Western Amazon: A cross-sectional study. Int J Women's Health. 2018;24(10):477-86. http://dx.doi.org/10.2147/IJWH.S169504

42. Kilıç M. Incidence and risk factors of urinary incontinence in women visiting Family Health Centers. Springerplus. 2016;5(1):1331. http://dx.doi.org/10.1186/s40064-016-2965-z

43. Demircan N. What are the probable predictors of urinary incontinence during pregnancy? PeerJ. 2016;27(4):e2283. http://dx.doi.org/10.7717/peerj.2283 
44. Knepfler T, Valero E, Triki E, Chilintseva N, Koensgen S, Rohr S. Bariatric surgery improves female pelvic floor disorders. J Visc Surg. 2016;153(2):95-9. http://dx.doi.org/10.1016/j.jviscsurg.2015.11.011

45. Barbosa L, Boaviagem A, Moretti E, Lemos A. Multiparity, age and overweight/obesity as risk factors for urinary incontinence in pregnancy: A systematic review and meta-analysis. Int Urogynecol J. 2018;29(10)1413-27. http://dx.doi.org/10.1007/s00192-018-3656-9

Received: December 7, 2018

Final Version: August 21, 2019

Approved: October 1, 2019 